\title{
Molecular Imaging and Quantitation of EphA2 Expression in Xenograft Models with ${ }^{89} \mathrm{Zr}$-DS-8895a
}

\author{
Ingrid J.G. Burvenich*1,2, Sagun Parakh*1-3 ${ }^{1}$, Hui K. Gan ${ }^{1-3}$, Fook-Thean Lee ${ }^{1}$, Nancy Guo ${ }^{1}$, Angela Rigopoulos ${ }^{1}$, \\ Sze-Ting Lee ${ }^{1,4}$, Sylvia Gong ${ }^{4}$, Graeme J. O’ Keefe ${ }^{3,4}$, Henri Tochon-Danguy ${ }^{4}$, Masakatsu Kotsuma ${ }^{5}$, Jun Hasegawa ${ }^{6}$, \\ Giorgio Senaldi ${ }^{7}$, and Andrew M. Scott ${ }^{1,3,4,8}$ \\ ${ }^{I}$ Tumour Targeting Laboratory, Ludwig Institute for Cancer Research and Olivia Newton-John Cancer Research Institute, Melbourne, \\ Australia; ${ }^{2}$ School of Cancer Medicine, La Trobe University, Melbourne, Australia; ${ }^{3}$ Department of Medical Oncology, Austin Health, \\ Heidelberg, Melbourne, Australia; ${ }^{4}$ Department of Molecular Imaging and Therapy, Austin Health, Melbourne, Australia; \\ ${ }^{5}$ Translational Medicine and Clinical Pharmacology Department, Daiichi-Sankyo Co., Ltd., Tokyo, Japan; ${ }^{6}$ Biologics Pharmacology \\ Research Laboratories, Daiichi-Sankyo Co., Ltd., Tokyo, Japan; ${ }^{7}$ Department of Translational Medicine and Clinical Pharmacology, \\ Daiichi-Sankyo Pharma Development, Edison, New Jersey; and ${ }^{8}$ Department of Medicine, University of Melbourne, Melbourne, \\ Australia
}

Subtype A2 of the erythropoietin-producing hepatocellular tyrosine kinase (EphA2) cell surface receptor is expressed in a range of epithelial cancers. This study evaluated the molecular imaging of EphA2 expression in vivo in mouse tumor models using SPECT/MR and PET/MR and a humanized anti-EphA2 antibody, DS-8895a. Methods: DS-8895a was labeled with ${ }^{111} \mathrm{In},{ }^{125} \mathrm{I}$, and ${ }^{89} \mathrm{Zr}$ and assessed for radiochemical purity, immunoreactivity (Lindmo analysis), antigen-binding affinity (Scatchard analysis), and serum stability in vitro. In vivo biodistribution, imaging, and pharmacokinetic studies were performed with SPECT/MR and PET/MR. A dose-escalation study was also performed to determine EphA2 receptor saturability through tissue and imaging quantitative analysis. Results: All conjugates demonstrated good serum stability and specific binding to EphA2-expressing cells in vitro. In vivo biodistribution studies showed high uptake of ${ }^{111} \mathrm{In}-\mathrm{CHX}-\mathrm{A}^{\prime \prime}-\mathrm{DTPA}-\mathrm{DS}-$ 8895a and ${ }^{89} \mathrm{Zr}$-Df-Bz-NCS-DS-8895a in EphA2-expressing xenograft models, with no specific uptake in normal tissues. In comparison, retention of ${ }^{125}$ I-DS-8895a in tumors was lower because of internalization of the radioconjugate and dehalogenation. These results were confirmed by SPECT/MR and PET/MR. EphA2 receptor saturation was observed at the $30 \mathrm{mg} / \mathrm{kg}$ dose. Conclusion: Molecular imaging of tumor uptake of DS-8895a allows noninvasive measurement of EphA2 expression in tumors in vivo and determination of receptor saturation. ${ }^{89} \mathrm{Zr}-\mathrm{Df}-\mathrm{Bz}-\mathrm{NCS}-\mathrm{DS}-8895 \mathrm{a}$ is suited for human bioimaging trials on the basis of superior imaging characteristics and will inform DS-8895a dose assessment and patient response evaluation in clinical trials.

Key Words: bioimaging; DS-8895a; EphA2; ${ }^{89} \mathrm{Zr}$; cancer

J Nucl Med 2016; 57:974-980

DOI: 10.2967/jnumed.115.169839

Received Nov. 16, 2015; revision accepted Jan. 29, 2016.

For correspondence or reprints contact: Andrew M. Scott, Tumour Targeting Laboratory, Olivia Newton-John Cancer Research Institute, 145163 Studley Rd., Heidelberg, Victoria 3084, Australia.

E-mail: andrew.scott@onjcri.org.au

${ }^{*}$ Contributed equally to this work.

Published online Mar. 3, 2016.

COPYRIGHT (C 2016 by the Society of Nuclear Medicine and Molecular Imaging, Inc.
$\mathbf{T}$

he erythropoietin-producing hepatocellular (Eph) tyrosine kinase receptor group is the largest known family of tyrosine kinase receptors. The receptors consist of an extracellular ligand binding domain, a short transmembrane region, and a cytoplasmic kinase domain. There are 2 subclasses of receptor, EphA (EphA1-EphA10) and EphB (EphB1EphB6), based on the sequence homologies of the extracellular domain and their binding affinity to glycosylphosphatidylinositol-linked ephrin A (ephrin A1-A5) or transmembrane ephrin B (ephrin B1-B3) ligands (1-3). Activation of the Eph receptor kinase domain can result from several processes, including binding of ligand to receptor, resulting in activation of downstream pathways; contact-dependent cell-cell communication (2); and crosstalk with other signaling systems. Eph/ephrin interactions are particularly important during embryonic development but are also involved in adult tissue homeostasis as they have roles in the development of neuronal pathways, axon guidance formation, maintenance and repair of synaptic junctions, vascular development, and epithelial homeostasis (4-7).

The EphA2 receptor is strongly overexpressed in several types of cancer, including glioblastoma $(8,9)$ and cancers of the ovary $(10)$, prostate gland (11), pancreas (12), and esophagus (13). Its expression has been associated with poor prognosis, increased metastasis, and decreased survival $(14,15)$. DS-8895a is an afucosylated humanized anti-EphA2 IgG1 monoclonal antibody with enhanced antibodydependent cellular cytotoxicity expressed using the proprietary Potelligent CHOK1SV system (Lonza and BioWa), showing in vitro and antitumor efficacy in EphA2-expressing xenograft models.

This study explored the radiolabeling of DS-8895a to ${ }^{125} \mathrm{I}$ and-via the bifunctional chelates $\mathrm{C}$-functionalized trans-cyclohexyldiethylenetriaminepentaacetic acid (CHX-A" -DTPA) and $p$-isothiocyanatobenzyldesferrioxamine (Df-Bz-NCS) — to ${ }^{111} \mathrm{In}$ and ${ }^{89} \mathrm{Zr}$, respectively, suitable for in vivo molecular imaging with SPECT $\left({ }^{125} \mathrm{I}\right.$ and $\left.{ }^{111} \mathrm{In}\right)$ and PET $\left({ }^{89} \mathrm{Zr}\right)$. The use of such radioconjugates for human bioimaging studies may inform the clinical development of DS-8895a through dose selection and patient response assessment.

\section{MATERIALS AND METHODS}

\section{Cell Culture}

The human breast carcinoma cell line MDA-MB-231 and the human lymphoblastic leukemia cell line CCRF-CEM were obtained 
from the American Type Culture Collection. The cells were cultured in Dulbecco modified Eagle medium or RPMI (Invitrogen) with $10 \%$ fetal calf serum and incubated at $37^{\circ} \mathrm{C}$ with $5 \% \mathrm{CO}_{2}$.

\section{Flow Cytometry}

EphA2 expression was assessed by staining $1 \times 10^{6}$ MDA-MB-231 cells with a $10 \mu \mathrm{g} / \mathrm{mL}$ dose of humanized DS-8895a, followed by phycoerythrin antihuman secondary antibody. Flow cytometric analysis was performed using Guava flow cytometry (Guava easyCyte 8HT flow cytometer, model 0500-4008; Guava Technologies).

\section{Conjugation of Deferoxamine-p-SCN to DS-8895a for Radiolabeling}

DS-8895a was obtained from Daiichi Sankyo Co., Ltd., and was chelated either with the bifunctional metal ion chelator CHX-A" -DTPA (Macrocyclics Inc.) at a 5.0-fold molar excess or with deferoxaminep-SCN (Df-Bz-NCS; Macrocyclics Inc.) at a 3.0-fold molar excess. Two-milligram aliquots of the conjugates in $50 \mathrm{mM}$ sodium acetate buffer (BDH/VWR Chemicals), pH 5.6, containing 5\% w/v sorbitol (BDH/VWR Chemicals) and $0.01 \% \mathrm{w} / \mathrm{v}$ polysorbate 80 (Croda) were stored at $-80^{\circ} \mathrm{C}$ until required.

\section{Radiolabeling and Quality Assurance}

Analytic-grade reagents, sterile technique, and pyrogen-free plasticware were used in all labeling steps. After chelation, DS-8895a was trace-radiolabeled as follows: ${ }^{125}$ I (Perkin Elmer) was attached on tyrosine residues via IODO-GEN chemistry (Perkin Elmer); ${ }^{111} \mathrm{In}$ (Mallinckrodt Australia Pty Ltd.), on lysine residues via the bifunctional metal ion chelating agent CHX-A"-DTPA; and ${ }^{89} \mathrm{Zr}$ (PerkinElmer), on lysine residues via the bifunctional metal ion chelating agent Df-Bz-NCS. For the 2 conjugates that used chemical chelation ( ${ }^{111}$ In-CHX-A" ${ }^{\prime \prime}$ DTPA-DS-8895a and ${ }^{89} \mathrm{Zr}-\mathrm{Df}-\mathrm{Bz}-\mathrm{NCS}-\mathrm{DS}-8895 \mathrm{a}$ ), the outcomes of chelation were also assessed. For the former, a solution containing $122 \mathrm{MBq}(3.2 \mathrm{mCi})$ of ${ }^{111} \mathrm{In}$ (Mallinckrodt Australia Pty Ltd.) was mixed with $0.5 \mathrm{mg}$ of CHX-A" -DTPA-DS-8895a for $20 \mathrm{~min}$. For the latter, a solution containing $44 \mathrm{MBq}(1.2 \mathrm{mCi})$ of ${ }^{89} \mathrm{Zr}$ (PerkinElmer) was mixed with $1.0 \mathrm{mg}$ of Df-Bz-NCS-DS-8895a for $30 \mathrm{~min}$. Radiolabeled products were purified on a Sephadex G50 column (Pharmacia) equilibrated with a sodium chloride injection (British Pharmacopeia 0.9\% w/v; Pfizer). To determine structural integrity after chelation and radiolabeling, constructs were analyzed under reducing and nonreducing condition on sodium dodecyl sulfate polyacrylamide gel electrophoresis (SDS-PAGE) gels. Antibody proteins from CHX-A"-DTPA-DS-8895a, Df-Bz-NCS-DS-8895a, and native DS-8895a samples were prepared with and without reducing agents in SDS-PAGE sample buffer. Aliquots of proteins ranging from 1.25 to $5.0 \mu \mathrm{g}$ were prepared accordingly and analyzed together with known-molecular-weight markers.

\section{Radiochemical Purity}

The amount of free versus bound antibody after radiolabeling was determined by instant thin-layer chromatography using silica gel impregnated glass fiber strips (Gelman Sciences, Inc.). Assays were performed in duplicate. Radioactivity was measured with an automated $\gamma$-counter (Wizard).

\section{Immunoreactivity and Scatchard Analysis}

The immunoreactive fraction of the radiolabeled DS-8895a constructs with EphA2-positive MDA-MB-231 cells was determined by linear extrapolation to binding at an infinite antigen excess using a Lindmo assay as previously described $(16,17)$. Scatchard analysis was used to calculate the apparent association constant and number of antibody molecules bound per cell (16).

\section{Serum Stability}

Serum stability was assessed by incubating $5.0 \mu \mathrm{g}$ of ${ }^{111}$ In-CHX-A"DTPA-DS-8895a, $2.5 \mu \mathrm{g}$ of ${ }^{125} \mathrm{I}-\mathrm{DS}-8895 \mathrm{a}$, and $5.0 \mu \mathrm{g}$ of ${ }^{89} \mathrm{Zr}$-DfBz-NCS-DS-8895a in $100 \mu \mathrm{L}$ of human serum at $37^{\circ} \mathrm{C}$ for $6 \mathrm{~d}$. Radiochemical purity and single-point immunoreactivity assays at $0 \mathrm{~d}$ (day of radiolabeling, no incubation), $2 \mathrm{~d}$, and $6 \mathrm{~d}$ of incubation were performed. MDA-MB-231 cells $\left(140 \times 10^{6}\right)$ were used in the singlepoint binding assays under conditions of antigen excess. Radioconstruct integrity was assessed by size-exclusion chromatography performed on a Superdex $200 \mathrm{HR} 10 / 30$ column (GE Healthcare) at a flow rate of $0.14 \mathrm{~mL} / \mathrm{min}$ and fraction size of $3.6 \mathrm{~mL}$. The elution buffer was phosphate-buffered saline at $\mathrm{pH}$ 7.4. Aliquots of serum containing radioconjugates were collected at the specified times and diluted to $1.0 \mathrm{~mL}$ using phosphate-buffered saline, and $10-\mu \mathrm{L}$ aliquots were retained for radioactive counting to determine recovery. The remaining diluted samples of the radioconjugates in serum were loaded onto the column for size-exclusion chromatography analysis.

\section{Animal Model}

In vivo investigations were performed on 5- to 6-wk-old female athymic BALB/c nu/nu mice (Animal Research Centre) bearing established EphA2-expressing breast cancer MDA-MB-231 xenografts or, for antigen-negative control xenografts, the human lymphoblastic leukemia cell line CCRF-CEM. All animal studies were approved by the Austin Hospital Animal Ethics Committee and were conducted in compliance with the Australian Code for the care and use of animals for scientific purposes. To establish tumors, EphA2-positive or -negative cells $\left(2 \times 10^{6}\right.$ cells $)$ in a total volume of $0.1 \mathrm{~mL}$ of phosphatebuffered saline were injected subcutaneously into the left underside flank of the mice. Tumor volume was calculated by the formula [(length $\times$ width $\left.^{2}\right) / 2$ ], where length is the longest axis and width is the measurement at right angles to length.

\section{Biodistribution Study}

In a first biodistribution study, BALB/c nu/nu mice with established MDA-MB-231 xenografts (tumor volume, $150-200 \mathrm{~mm}^{3}$ ) received a mixture of $0.185 \mathrm{MBq}$ of ${ }^{125} \mathrm{I}-\mathrm{DS}-8895 \mathrm{a}(5.0 \mu \mathrm{g}, 5.0 \mu \mathrm{Ci})$ or 0.6031 $\mathrm{MBq}$ of ${ }^{111} \mathrm{In}-\mathrm{CHX}-\mathrm{A}^{\prime \prime}$-DTPA-DS-8895a $(5.0 \mu \mathrm{g}, 16.3 \mu \mathrm{Ci})$ intravenously. In a second biodistribution study, BALB/c nu/nu mice with established MDA-MB-231 xenografts (tumor volume range, 207-844 $\mathrm{mg}$ ) or CCRF-CEM xenografts (tumor volume range, 129-503 mg) received a $0.1332-\mathrm{MBq}$ dose of ${ }^{89} \mathrm{Zr}$-Df-Bz-NCS-DS-8895a $(5.0 \mu \mathrm{g}$, $3.6 \mu \mathrm{Ci}$ ) intravenously. On day 0 ( $2 \mathrm{~h}$ after injection), 1, 2, 3, 5, 7, and 9 or 10 after injection, groups of mice bearing MDA-MB-231 tumors $(n=5)$ were sacrificed and biodistribution was assessed. For mice bearing EphA2-negative CCRF-CEM xenografts, biodistribution was assessed on only days 2 and 7 after injection.

At the designated time points, the mice were exsanguinated by cardiac puncture, and tumors and organs (liver, spleen, kidney, muscle, skin, bone [femur], lungs, heart, stomach, brain, small bowel, tail, and colon) were collected immediately. All samples were counted in a dual-channel $\gamma$-scintillation counter (Wizard; PerkinElmer). Triplicate standards prepared from the injected material were counted at each time point with tissue and tumor samples, enabling calculations to be corrected for the physical decay of the isotopes. The tissue distribution data were calculated as the mean \pm SD percentage injected dose (\%ID) per gram of tissue for the radiolabeled constructs per time point.

\section{Animal Imaging}

For in vivo SPECT imaging of ${ }^{111}$ In-labeled DS-8895a, a separate group of 5 mice received a higher dose of $2.035 \mathrm{MBq}(55 \mu \mathrm{Ci})$ of ${ }^{111} \mathrm{In}-\mathrm{CHX}-\mathrm{A}^{\prime \prime}$-DTPA-DS-8895a $(15.7 \mu \mathrm{g})$ and were imaged by SPECT and MR on days 0 ( $2 \mathrm{~h}$ after injection), 3, and 7 using 


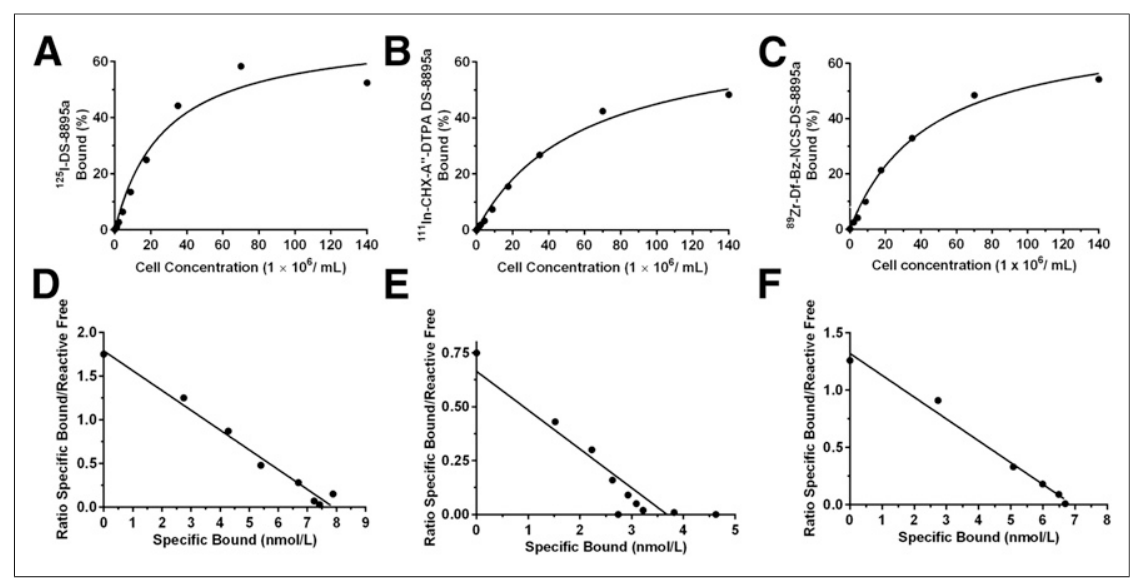

FIGURE 1. (A-C) Lindmo plots showing in vitro binding of ${ }^{125}$ I-DS-8895a (A), ${ }^{111}$ In-CHX-A"-DTPADS-8895a (B), and ${ }^{89 Z r-D f-B z-N C S-D S-8895 a ~(C) ~ t o ~ i n c r e a s i n g ~ c o n c e n t r a t i o n s ~ o f ~ E p h A 2-p o s i t i v e ~}$ MDA-MB-231 cells. (D-F) Scatchard plots showing in vitro binding of ${ }^{125}$ I-DS-8895a (D), ${ }^{111} \mathrm{In}-$ CHX-A"-DTPA-DS-8895a (E), and ${ }^{89}$ Zr-Df-Bz-NCS-DS-8895a (F) to MDA-MB-231 cells.

\section{Statistical Analysis}

A paired $t$ test was used to determine significant differences in the ${ }^{89} \mathrm{Zr}$ biodistribution results between tissues (\% ID/g). An unpaired $t$ test was used to determine significant differences in pharmacokinetic parameters between the ${ }^{111} \mathrm{In}$ - and ${ }^{89} \mathrm{Zr}$-labeled DS-8895a antibodies. For multiple comparisons, 1-way ANOVA was used. All analyses were done using GraphPad Prism, version 6.03. Data are presented as the mean $\pm \mathrm{SD}$, unless stated differently.

\section{RESULTS}

\section{Conjugation, Radiolabeling, and Quality Assurance}

The results of chelation and radiolabeling were assessed using MDA-MB-231 cells, which were confirmed to have high EphA2 expression. All 3 radioconjugates were

dedicated small-animal SPECT/CT and PET/MR (nanoScan; Mediso) cameras. For in vivo PET imaging of ${ }^{89} \mathrm{Zr}$-labeled DS-8895a, a separate 5-mouse group received a $2.775-\mathrm{MBq}(75 \mu \mathrm{Ci})$ dose of ${ }^{89} \mathrm{Zr}$-DfBz-NCS-DS-8895a $(104.2 \mu \mathrm{g})$ and was imaged with PET and MR on days 0 ( $2 \mathrm{~h}$ after injection), 2 , and 7 using the nanoScan camera.

\section{Pharmacokinetics}

Serum from blood collected from tumor-bearing mice injected with radiolabeled antibody was aliquoted and counted in a $\gamma$-counter (Packard). Triplicate standards prepared from the injected material were also counted at each time point to enable calculations to be corrected for the isotope physical decay. The results of the serum were expressed as \% ID per liter, and the serum concentrations $(\mu \mathrm{g} / \mathrm{mL})$ were calculated. A 2-compartment intravenous bolus model with macroparameters, no lag time, and first-order elimination was fitted to serum data for each animal using unweighted nonlinear least squares with Phoenix WinNonLin, model 8 (Certara). The following pharmacokinetic parameters were estimated: half-lives of the initial and terminal phases of disposition, volume at steady state, maximum serum concentration, area under the serum-concentration curve extrapolated to infinite time, and total serum clearance.

\section{EphA2 Saturation In Vivo}

The influence of DS-8895a protein dose on tumor uptake and EphA2 saturation in vivo was determined in a separate biodistribution and PET/MR imaging study using ${ }^{89} \mathrm{Zr}-\mathrm{Df}-\mathrm{Bz}-\mathrm{NCS}-\mathrm{DS}-8895 \mathrm{a}$. For the biodistribution study, 3 groups of mice $(n=5)$ were injected with $0.2775 \mathrm{MBq}$ of ${ }^{89} \mathrm{Zr}$-Df-Bz-NCS-DS-8895a (5.5 $\left.\mu \mathrm{g}, 7.5 \mu \mathrm{Ci}\right)$ combined with different amounts of unlabeled DS-8895a to achieve a total protein dose of $0.3,3$, and $30 \mathrm{mg} / \mathrm{kg}$ in a total volume of $0.1 \mathrm{~mL}$ of $0.9 \% \mathrm{w} / \mathrm{v} \mathrm{NaCl}$. On days 2 and 7 after injection, all animals were sacrificed and organs were collected as described above. The tissue distribution data were calculated as mean $\pm \mathrm{SD} \% \mathrm{ID} / \mathrm{g}$.

In parallel, 1-2 mice of each group were imaged with PET/MRI on days 0 ( $2 \mathrm{~h}$ after injection), 2, and 7 after injection using the nanoScan camera as described before, and the images was analyzed. Tumor uptake $\left(\mathrm{kBq} / \mathrm{cm}^{3}\right)$ was determined by marking volumes of interest on cross-sectional PET images. Tumor volume $\left(\mathrm{cm}^{3}\right)$ was determined on the basis of marked volumes of interest on cross-sectional MR images. To convert $\left(\mathrm{kBq} / \mathrm{cm}^{3}\right) / \mathrm{mL}$ to $\% \mathrm{ID} / \mathrm{mL}$, total-body uptake $\left(\mathrm{kBq} / \mathrm{cm}^{3}\right)$ in mice was measured on day 0 as an approximation of injected dose. shown to be intact by SDS-PAGE analysis under reducing and nonreducing conditions. Data were also obtained on the stability of ${ }^{111} \mathrm{In}-\mathrm{CHX}-\mathrm{A}^{\prime \prime}$-DTPA-DS-8895 (purity, 91.2\%; immunoreactivity, 44.0\%), ${ }^{125}$ I-DS-8895a (purity, 94.5\%; immunoreactivity, $46.6 \%$ ), and ${ }^{89} \mathrm{Zr}-\mathrm{Df}-\mathrm{Bz}-\mathrm{NCS}-\mathrm{DS}-8895 \mathrm{a}$ (purity, $97.5 \%$; immunoreactivity, $51 \%$ ) at $6 \mathrm{~d}$ in human serum.

Using a Lindmo binding assay with MDA-MB-231 cells, the ${ }^{125}$ I-DS-8895a chelate showed $98.9 \%$ radiochemical purity, immunoreactivity of $53.8 \%$, and an apparent association constant of

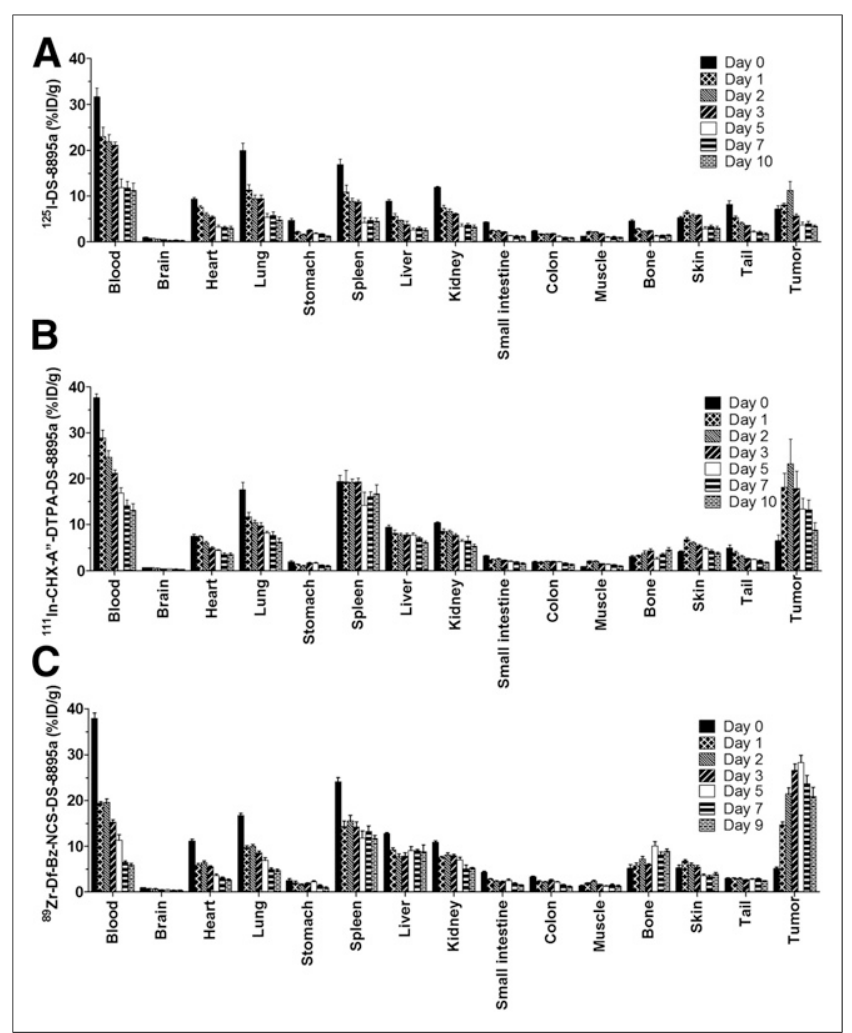

FIGURE 2. Biodistribution properties of ${ }^{125} \mathrm{I}-\mathrm{DS}-8895 \mathrm{a}(\mathrm{A}),{ }^{111} \mathrm{In}-\mathrm{CHX}-$ A"-DTPA-DS-8895a (B), and ${ }^{89}$ Zr-Df-Bz-NCS-DS-8895a (C) in MDA-MB231-xenografted BALB/c nu/nu mice. Bars indicate mean $\pm \mathrm{SD}(n=5)$. 


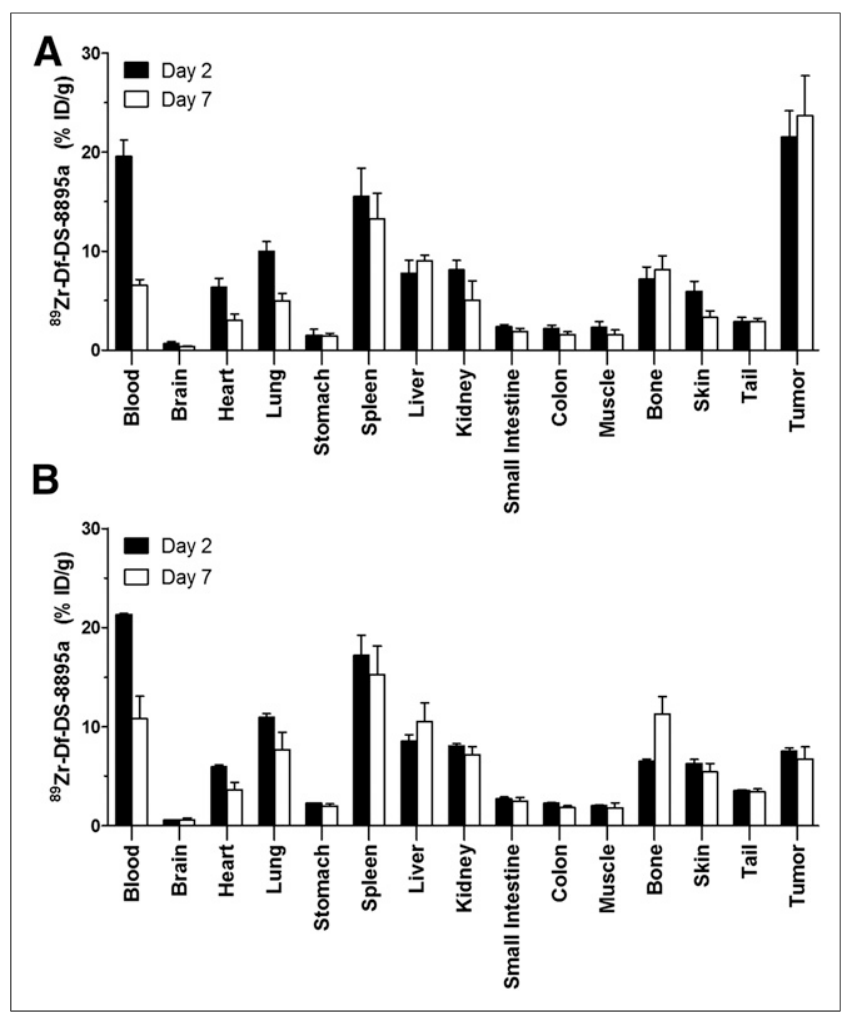

FIGURE 3. Biodistribution properties of ${ }^{89} \mathrm{Zr}$-Df-Bz-NCS-DS-8895a in BALB/c nu/nu mice bearing EphA2-positive MDA-MB-231 breast tumors (A) and EphA2-negative CCRF-CEM human lymphoblastic leukemia (B) on days 2 and 7 after injection. Bars indicate mean $\pm \operatorname{SD}(n=5)$.

$2.14 \times 10^{8} \mathrm{M}^{-1}$ (Fig. 1A). The ${ }^{111}$ In-CHX-A" -DTPA-DS-8895 chelate showed high purity $(99.6 \%)$, immunoreactivity of $55.4 \%$, and an apparent association constant of $2.10 \times 10^{8} \mathrm{M}^{-1}$ (Fig. 1B). ${ }^{89} \mathrm{Zr}$-Df-Bz-NCS-DS-8895a had a radiochemical purity of $99.6 \%$ and immunoreactivity of $54.2 \%$ (Fig. 1C). Scatchard analysis indicated that the ${ }^{111}$ In-conjugate bound to approximately 40,000 sites per cell (Fig. 1D), compared with 60,000 antibody binding sites per cell for both ${ }^{125} \mathrm{I}-\mathrm{DS}-8895 \mathrm{a}$ and ${ }^{89} \mathrm{Zr}$-Df-Bz-NCS-DS8895a (Figs. 1E and 1F).

\section{Biodistribution}

Figure 2 summarizes the biodistribution results for ${ }^{125} \mathrm{I}-\mathrm{DS}$ 8895a, ${ }^{111}$ In-CHX-A "-DTPA-DS-8895a, and ${ }^{89}$ Zr-Df-Bz-NCSDS-8895a in EphA2-positive MDA-MB-231 tumors. ${ }^{125}$ I-DS8895 a tumor uptake was lowest, reaching only $11.23 \pm 4.34 \% \mathrm{ID} / \mathrm{g}$ by day 2 after injection and declining to $3.42 \pm 0.73 \% \mathrm{ID} / \mathrm{g}$ by day 10. In comparison, uptake of ${ }^{111} \mathrm{In}-\mathrm{CHX}-\mathrm{A}^{\prime \prime}$-DTPA-DS-8895a reached a maximum of $23.19 \pm 12.17 \% \mathrm{ID} / \mathrm{g}$ on day 2 after injection and gradually declined to $8.76 \pm 3.65 \% \mathrm{ID} / \mathrm{g}$ by day 10 . Uptake of ${ }^{89}$ Zr-Df-Bz-NCS-DS-8895a reached $26.59 \pm 3.04 \% \mathrm{ID} / \mathrm{g}$ on day 3 after injection and then stayed at $28.24 \pm 3.66 \% \mathrm{ID} / \mathrm{g}$ until day 5 before gradually declining to $20.82 \pm 4.67 \% \mathrm{ID} / \mathrm{g}$ by day 9 .

Organs with a high blood supply, including the heart, kidneys, liver, spleen, and lungs, showed high initial uptake of radiolabeled DS-8895a (Fig. 2) consistent with biodistribution and catabolism of radiolabeled antibodies. Uptake of radioiodinated DS-8895a in these organs declined over time. In contrast, uptake in the spleen, liver, and bone remained high or increased over time with the
${ }^{111} \mathrm{In}$ - and ${ }^{89} \mathrm{Zr}$-conjugates, consistent with catabolism of radiometal-conjugated antibodies (Fig. 2).

The tumor-to-blood ratio for ${ }^{125}$ I-DS-8895a increased from 0.23 ( $2 \mathrm{~h}$ after injection) to 0.33 (day 7 after injection). In comparison, the tumor-to-blood ratio increased from 0.17 ( $2 \mathrm{~h}$ after injection) to 0.94 (day 7 after injection) for ${ }^{111}$ In-CHX-A" -DTPA-DS-8895a and from 0.14 ( $2 \mathrm{~h}$ after injection) to 3.62 (day 7 after injection) for ${ }^{89} \mathrm{Zr}-\mathrm{Df}-$ Bz-NCS-DS-8895a. The tumor specificity of ${ }^{89} \mathrm{Zr}-\mathrm{Df}-\mathrm{Bz}-\mathrm{NCS}-\mathrm{DS}-$ 8895a was confirmed by assessing uptake in the EphA2-negative tumor CCRF-CEM (Fig. 3). Uptake of ${ }^{89}$ Zr-Df-Bz-NCS-DS-8895a in CCRF-CEM tumors was significantly lower than that of MDAMB-231 on days $2(7.58 \pm 0.29 \% \mathrm{ID} / \mathrm{g}$ vs. $21.52 \pm 2.65$, respectively; $\left.P=8.40 \times 10^{-6}\right)$ and $7(6.73 \pm 1.21 \% \mathrm{ID} / \mathrm{g}$ vs. $23.64 \pm$ 4.06, respectively; $\left.P=4.43 \times 10^{-5}\right)$.

In Vivo Molecular Imaging of EphA2 Expression in Tumors

Whole-body SPECT/MR images showed localization of ${ }^{111} \mathrm{In}$ CHX-A"-DTPA-DS-8895a to tumors at early time points after injection (from $2 \mathrm{~h}$ onward) (Fig. 4A). ${ }^{111} \mathrm{In}-\mathrm{CHX}-\mathrm{A}^{\prime \prime}$-DTPADS-8895a uptake in tumors was more discernible at later time points of up to $7 \mathrm{~d}$, even in small tumors.

Similarly, whole-body PET/MR images showed localization of ${ }^{89} \mathrm{Zr}$-Df-Bz-NCS-DS-8895a (Fig. 4B) to tumors at early time points after injection (from $2 \mathrm{~h}$ onward). ${ }^{89} \mathrm{Zr}-\mathrm{Df}-\mathrm{Bz}-\mathrm{NCS}-\mathrm{DS}-$ 8895a uptake in tumors was also clearly discernible at later time points of up to $7 \mathrm{~d}$ after injection, even in small tumors. Some spleen, liver, and bone activity, consistent with catabolism of ${ }^{89} \mathrm{Zr}$-Df-Bz-NCS, was also observed.

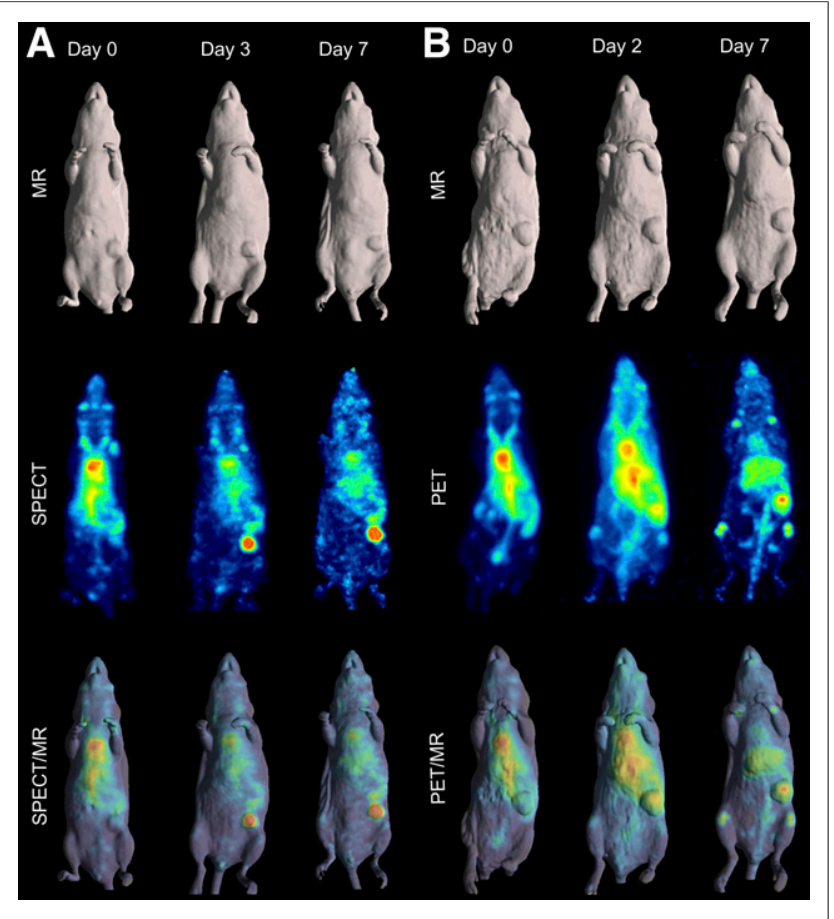

FIGURE 4. (A) MR (surface-rendered), SPECT (maximum-intensity projection), and fused SPECT/MR images of MDA-MB-231-xenografted mice at $2 \mathrm{~h}$ (day 0), $3 \mathrm{~d}$, and $7 \mathrm{~d}$ after injection of ${ }^{111} \mathrm{In}-\mathrm{CHX}-\mathrm{A}^{\prime \prime}-\mathrm{DTPA}$ DS-8895a. (B) MR (surface-rendered), PET (maximum-intensity projection), and fused PET/MR images of MDA-MB-231-xenografted mice at $2 \mathrm{~h}$ (day 0), $2 \mathrm{~d}$, and $7 \mathrm{~d}$ after injection of ${ }^{89} \mathrm{Zr}$-Df-Bz-NCS-DS-8895a. 


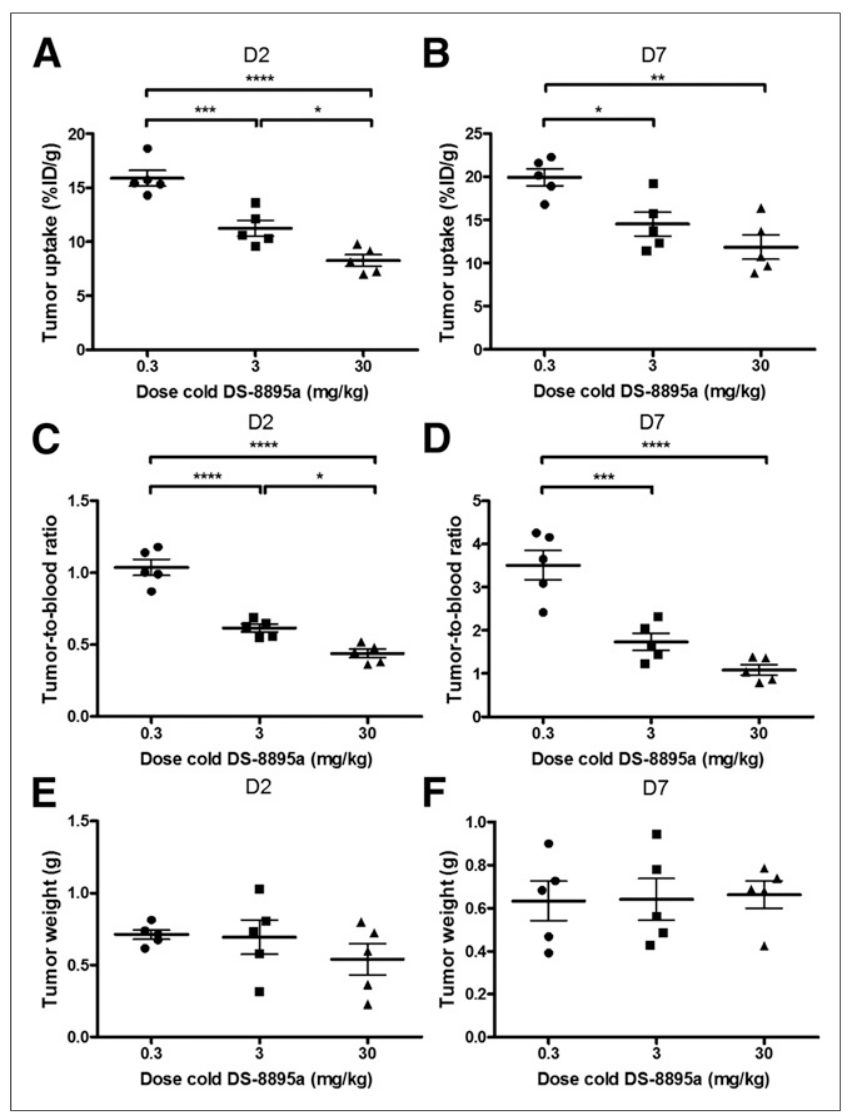

FIGURE 5. Influence of cold-dose DS-8895a on tumor uptake of ${ }^{89} \mathrm{Zr}$ Df-Bz-NCS-DS-8895a in BALB/c nu/nu mice bearing MDA-MB-231 xenografts on days 2 (A) and 7 (B) after injection, and tumor-to-blood ratios on days $2(C)$ and 7 (D) after injection. There was no significant difference in average tumor size among the various dose levels on days $2(\mathrm{E})$ and $7(\mathrm{~F})$ after injection. Bars indicate mean $\pm \mathrm{SD}(n=5)$. ${ }^{*} P<0.05$. ${ }^{\star \star} P<0.005$. ${ }^{\star \star \star} P<0.0005$. ${ }^{\star \star \star \star} P<0.0001$.

\section{In Vivo Receptor Saturation}

A combination study of biodistribution and PET/MR imaging explored saturation of the EphA2 receptor in vivo. A biodistribution study compared $0.3,3$, and $30 \mathrm{mg} / \mathrm{kg}$ doses of ${ }^{89} \mathrm{Zr}$ labeled DS-8895a in mice bearing MDA-MB-231 xenografts (tumor volume, $0.647 \pm 0.194 \mathrm{~g}$ ). No significant differences were observed in blood and normal-tissue biodistribution patterns.

A clear protein dose effect was evident for MDA-MB-231 tumor uptake. At all study time points, the highest tumor uptake was observed with the $0.3 \mathrm{mg} / \mathrm{kg}$ DS-8895a dose and the lowest with the $30 \mathrm{mg} / \mathrm{kg}$ dose, and significantly higher tumor-to-blood ratios were observed with the $0.3 \mathrm{mg} / \mathrm{kg}$ protein dose than with the $30 \mathrm{mg} / \mathrm{kg}$ dose over the duration of the study (Fig. 5). No significant differences in average tumor size among the various doselevel groups were observed, indicating that the protein dose effect was not influenced by tumor size.

Representative individual-animal PET/MR images obtained with a $0.3,3$, and $30 \mathrm{mg} / \mathrm{kg}$ dose of ${ }^{89} \mathrm{Zr}$-labeled DS-8895a on days 2 and 7 are shown in Figure 6. MDA-MB-231 tumor uptake was clearly evident on days 2 (Fig. 6A) and 7 (Fig. 6B) at all dose levels. Compared with the $0.3 \mathrm{mg} / \mathrm{kg}$ dose, both the 3 and the 30 $\mathrm{mg} / \mathrm{kg}$ doses showed less uptake in the xenografts with time, consistent with the measured \%ID/g levels and tumor-to-blood ratios as obtained from the biodistribution study (Fig. 5). Quantitative image analysis of tumor volumes and tumor uptake confirmed a substantial reduction in uptake with both the $3 \mathrm{mg} / \mathrm{kg}$ dose and the $30 \mathrm{mg} / \mathrm{kg}$ dose.

\section{Pharmacokinetics}

The mean pharmacokinetic parameters for ${ }^{111} \mathrm{In}$ - and ${ }^{89} \mathrm{Zr}$ labeled DS-8895a administered at a protein dose of $5 \mu \mathrm{g}(0.25$ $\mathrm{mg} / \mathrm{kg}$ ) are presented in Table 1 . An unpaired $t$ test determined significant differences in pharmacokinetic parameters between the two radioconjugates. The slightly faster clearance observed with ${ }^{89} \mathrm{Zr}$-labeled DS-8895a is consistent with its higher uptake in tumors.

\section{DISCUSSION}

We have shown that it is feasible to radiolabel DS-8895a, an antiEphA2 antibody, with several radioligands suitable for molecular imaging with SPECT $\left({ }^{125} \mathrm{I}\right.$ and $\left.{ }^{111} \mathrm{In}\right)$ and PET $\left({ }^{89} \mathrm{Zr}\right)$. Chelation and radiolabeling did not alter the structural integrity or immunoreactivity of the constructs. These constructs were also stable in plasma for up to $6 \mathrm{~d}$.

The in vivo biodistribution and imaging patterns showed that ${ }^{125}$ I-DS-8895a had the lowest tumor uptake of all the conjugates at all time points tested. This finding likely reflects internalization and translocation of ${ }^{125}$ I-DS-8895a to the lysosomes, with subsequent degradation of the conjugate and release of the ${ }^{125} \mathrm{I}$ catabolites from the cells. In contrast, ${ }^{111} \mathrm{In}$ - and ${ }^{89} \mathrm{Zr}$-catabolites

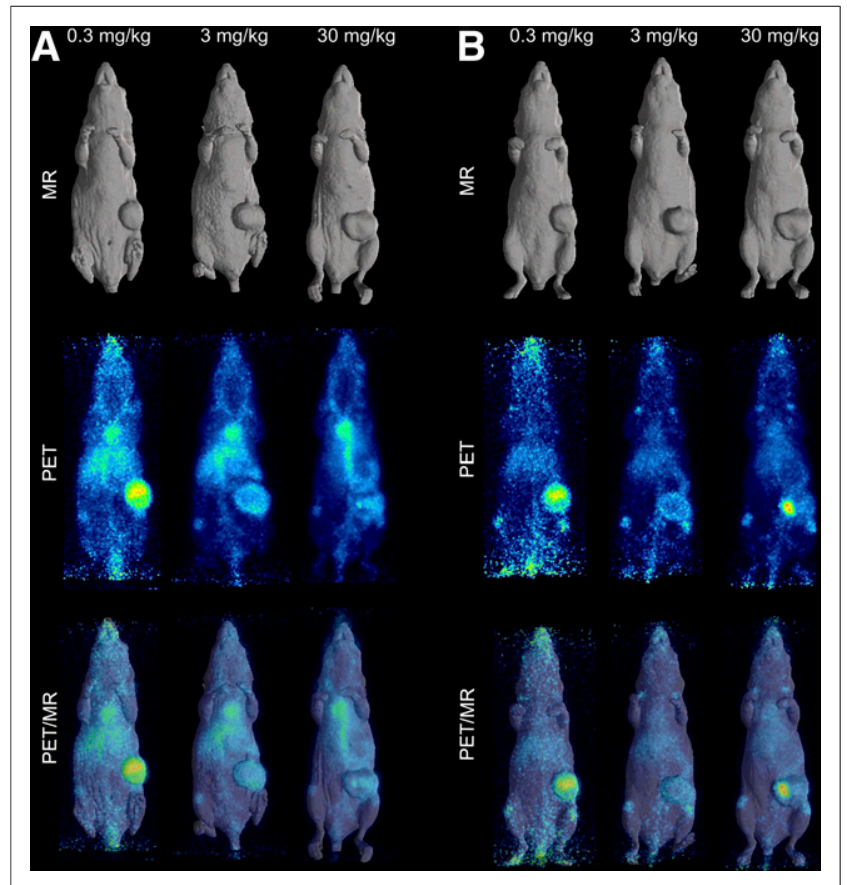

FIGURE 6. In vivo saturation of ${ }^{89} \mathrm{Zr}$-labeled DS-8895a as demonstrated by PET/MR on days 2 (A) and 7 (B) after injection. Representative whole-body surface-rendered MR images, maximum-intensityprojection PET images, and fused PET/MR images are shown for each time point with different dose levels of cold DS-8895a $(0.3,3$, and $30 \mathrm{mg} / \mathrm{kg}$ ). Hot spot in tumor on day 7 PET and PET/MR images of mouse receiving $30 \mathrm{mg} / \mathrm{kg}$ is due to blood crust. 
TABLE 1

Pharmacokinetic Parameters of ${ }^{89} \mathrm{Zr}$ - and ${ }^{111} \mathrm{In}$-Labeled DS-8895a in MDA-MB-231 Tumor-Bearing Mice

\begin{tabular}{lccr}
\hline \multicolumn{1}{c}{ Parameter } & 89Zr-labeled DS-8895a & 111/n-labeled DS-8895a & $P$ \\
\hline AUC $(\mathrm{h} \times \mu \mathrm{g} / \mathrm{mL})$ & $185.7 \pm 26.96$ & $417.6 \pm 90.60$ & 0.0033 \\
$t_{1 / 2 \mathrm{a}}(\mathrm{h})$ & $1.48 \pm 0.26$ & $8.85 \pm 4.97$ & 0.0295 \\
$t_{1 / 2 \beta}(\mathrm{h})$ & $102.4 \pm 14.65$ & $215.1 \pm 72.88$ & 0.0244 \\
$\mathrm{C}_{\max }(\mu \mathrm{g} / \mathrm{mL})$ & $3.03 \pm 0.43$ & $2.07 \pm 0.29$ & 0.0033 \\
$\mathrm{C}_{\mathrm{L}}(\mathrm{mL} / \mathrm{h})$ & $0.027 \pm 0.004$ & $0.012 \pm 0.002$ & $<0.0001$ \\
$\mathrm{~V}_{\mathrm{ss}}(\mathrm{mL})$ & $3.90 \pm 0.11$ & $3.59 \pm 0.43$ & 0.1845
\end{tabular}

AUC $=$ area under curve; $t_{1 / 2 \alpha}=$ half-life of initial phase of disposition; $t_{1 / 2 \beta}=$ half-life of terminal phase of disposition; $C_{\max }=$ maximum plasma-serum concentration; $\mathrm{C}_{\mathrm{L}}=$ total serum clearance; $\mathrm{V}_{\mathrm{ss}}=$ volume of distribution at steady state.

Data are mean \pm SD $(n=5)$. $P$ values are result of unpaired $t$ test; Welch correction was used when variances were significantly different.

are trapped in the cells, allowing higher retention of ${ }^{111} \mathrm{In}-$ and ${ }^{89} \mathrm{Zr}$-conjugates in the xenografts.

In vivo targeting of tumor with ${ }^{111} \mathrm{In}-\mathrm{CHX}-\mathrm{A}^{\prime \prime}$-DTPA- and ${ }^{89} \mathrm{Zr}$ Df-Bz-NCS-DS-8895a was similar, although the latter was higher, particularly at later time points. The results for ${ }^{89} \mathrm{Zr}-\mathrm{Df}-\mathrm{Bz}-\mathrm{NCS}-\mathrm{DS}-$ 8895 a were superior to those of a prior study of anti-EphA2 ${ }^{64} \mathrm{Cu}-$ DOTA-1C1, particularly at later time points, when maximal uptake in human tumors is anticipated and when ${ }^{89} \mathrm{Zr}$ half-life is better suited to human trials (18). These results were comparable to uptake of other ${ }^{89} \mathrm{Zr}$-labeled antibodies in animal models, including trastuzumab (Herceptin; Genentech), although expression of ErbB2 on tumor cell surfaces is much higher than that of EphA2 (19-22).

To our knowledge, the impact of protein dose on EphA2 targeting and receptor saturation in vivo has not previously been assessed; reduced uptake of ${ }^{89} \mathrm{Zr}$-Df-Bz-NCS-DS-8895a in tumors was observed at the $3 \mathrm{mg} / \mathrm{kg}$ dose level, with slightly lower uptake at the $30 \mathrm{mg} / \mathrm{kg}$ level. The $3 \mathrm{mg} / \mathrm{kg}$ dose is within the likely range for clinical trials, indicating that EphA2 receptor saturation may occur during dose escalation, thus justifying a bioimaging approach to dose assessment in early-phase trials (23).

In all, we have developed 3 radiolabeled conjugates for DS$8895 \mathrm{a}$, and ${ }^{89} \mathrm{Zr}$-Df-Bz-NCS-DS-8895a is our lead compound because of its superior imaging and tumor uptake characteristics. These findings have direct clinical relevance, as we have previously shown in several first-in-human bioimaging studies an excellent correlation between preclinical and clinical biodistribution data and $\gamma$-camera imaging using radiolabeled monoclonal antibodies (24-27).

\section{CONCLUSION}

We have shown that molecular imaging of radiolabeled DS8895 a allows noninvasive quantitative assessment of EphA2 expression, and receptor saturation, in tumor models. These results are directly relevant to the design and conduct of DS$8895 \mathrm{a}$ trials on cancer patients, and a clinical trial of ${ }^{89} \mathrm{Zr}-\mathrm{Df}-$ Bz-NCS-DS-8895a on patients with EphA2-expressing tumors is under way.

\section{DISCLOSURE}

The costs of publication of this article were defrayed in part by the payment of page charges. Therefore, and solely to indicate this fact, this article is hereby marked "advertisement" in accordance with 18 USC section 1734. This work was supported by funding from Daiichi-Sankyo Co., Ltd., by the Operational Infrastructure Support program of the Victorian State Government, and by the Solid Target Laboratory, an ANSTO-Austin-LICR Partnership. We acknowledge the Australian Cancer Research Foundation for providing funds to purchase the small-animal PET/MR and SPECT/CT imaging equipment. Masakatsu Kotsuma, Jun Hasegawa, and Giorgio Senaldi are employees of Daiichi-Sankyo Co., Ltd. No other potential conflict of interest relevant to this article was reported.

\section{REFERENCES}

1. Gale NW, Yancopoulos GD. Ephrins and their receptors: a repulsive topic? Cell Tissue Res. 1997;290:227-241.

2. Kullander K, Klein R. Mechanisms and functions of Eph and ephrin signalling. Nat Rev Mol Cell Biol. 2002;3:475-486.

3. Murai KK, Pasquale EB. 'Eph'ective signaling: forward, reverse and crosstalk. $J$ Cell Sci. 2003;116:2823-2832.

4. Pasquale EB. Eph-ephrin bidirectional signaling in physiology and disease. Cell. 2008;133:38-52.

5. Flanagan JG, Vanderhaeghen P. The ephrins and Eph receptors in neural development. Annu Rev Neurosci. 1998;21:309-345.

6. Yamaguchi Y, Pasquale EB. Eph receptors in the adult brain. Curr Opin Neurobiol. 2004;14:288-296.

7. Hafner C, Schmitz G, Meyer S, et al. Differential gene expression of Eph receptors and ephrins in benign human tissues and cancers. Clin Chem. 2004;50: 490-499.

8. Wykosky J, Gibo DM, Stanton C, Debinski W. Interleukin-13 receptor alpha 2, EphA2, and Fos-related antigen 1 as molecular denominators of high-grade astrocytomas and specific targets for combinatorial therapy. Clin Cancer Res. 2008;14:199-208.

9. Wang LF, Fokas E, Bieker M, et al. Increased expression of EphA2 correlates with adverse outcome in primary and recurrent glioblastoma multiforme patients. Oncol Rep. 2008;19:151-156.

10. Thaker PH, Deavers M, Celestino J, et al. EphA2 expression is associated with aggressive features in ovarian carcinoma. Clin Cancer Res. 2004;10:51455150 .

11. Zeng G, Hu Z, Kinch MS, et al. High-level expression of EphA2 receptor tyrosine kinase in prostatic intraepithelial neoplasia. Am J Pathol. 2003;163: 2271-2276.

12. Duxbury MS, Ito H, Zinner MJ, Ashley SW, Whang EE. EphA2: a determinant of malignant cellular behavior and a potential therapeutic target in pancreatic adenocarcinoma. Oncogene. 2004;23:1448-1456.

13. Miyazaki T, Kato H, Fukuchi M, Nakajima M, Kuwano H. EphA2 overexpression correlates with poor prognosis in esophageal squamous cell carcinoma. Int $J$ Cancer. 2003;103:657-663. 
14. Liu F, Park PJ, Lai W, et al. A genome-wide screen reveals functional gene clusters in the cancer genome and identifies EphA2 as a mitogen in glioblastoma. Cancer Res. 2006;66:10815-10823.

15. Kinch MS, Moore MB, Harpole DH Jr. Predictive value of the EphA2 receptor tyrosine kinase in lung cancer recurrence and survival. Clin Cancer Res. 2003;9:613-618.

16. Lindmo T, Boven E, Cuttitta F, Fedorko J, Bunn PA Jr. Determination of the immunoreactive fraction of radiolabeled monoclonal antibodies by linear extrapolation to binding at infinite antigen excess. J Immunol Methods. 1984;72:77-89.

17. Lee FT, Rigopoulos A, Hall C, et al. Specific localization, gamma camera imaging, and intracellular trafficking of radiolabelled chimeric anti-G(D3) ganglioside monoclonal antibody KM871 in SK-MEL-28 melanoma xenografts. Cancer Res. 2001;61:4474-4482.

18. Cai W, Ebrahimnejad A, Chen K, et al. Quantitative radioimmunoPET imaging of EphA2 in tumor-bearing mice. Eur J Nucl Med Mol Imaging. 2007;34:2024-2036.

19. Dijkers EC, Kosterink JG, Rademaker AP, et al. Development and characterization of clinical-grade ${ }^{89} \mathrm{Zr}$-trastuzumab for HER2/neu immunoPET imaging. $J$ Nucl Med. 2009;50:974-981.

20. Janjigian YY, Viola-Villegas N, Holland JP, et al. Monitoring afatinib treatment in HER2-positive gastric cancer with ${ }^{18} \mathrm{~F}$-FDG and ${ }^{89} \mathrm{Zr}$-trastuzumab PET. J Nucl Med. 2013;54:936-943.
21. Holland JP, Divilov V, Bander NH, Smith-Jones PM, Larson SM, Lewis JS. ${ }^{89} \mathrm{Zr}-$ DFO-J591 for immunoPET of prostate-specific membrane antigen expression in vivo. J Nucl Med. 2010;51:1293-1300.

22. Deri MA, Zeglis BM, Francesconi LC, Lewis JS. PET imaging with ${ }^{89} \mathrm{Zr}$ : from radiochemistry to the clinic. Nucl Med Biol. 2013;40:3-14.

23. Burvenich IJ, Lee FT, Cartwright GA, et al. Molecular imaging of death receptor 5 occupancy and saturation kinetics in vivo by humanized monoclonal antibody CS-1008. Clin Cancer Res. 2013;19:5984-5993.

24. Scott AM, Lee FT, Tebbutt N, et al. A phase I clinical trial with monoclonal antibody ch806 targeting transitional state and mutant epidermal growth factor receptors. Proc Natl Acad Sci USA. 2007;104:4071-4076.

25. Scott AM, Lee FT, Jones R, et al. A phase I trial of humanized monoclonal antibody A33 in patients with colorectal carcinoma: biodistribution, pharmacokinetics, and quantitative tumor uptake. Clin Cancer Res. 2005;11:4810-4817.

26. Herbertson RA, Tebbutt NC, Lee FT, et al. Phase I biodistribution and pharmacokinetic study of Lewis Y-targeting immunoconjugate CMD-193 in patients with advanced epithelial cancers. Clin Cancer Res. 2009;15:6709-6715.

27. Herbertson RA, Tebbutt NC, Lee FT, et al. Targeted chemoradiation in metastatic colorectal cancer: a phase I trial of ${ }^{131} \mathrm{I}$-huA33 with concurrent capecitabine. $J$ Nucl Med. 2014;55:534-539. 